IRA-International Journal of Management \& Social Sciences

ISSN 2455-2267; Vol.05, Issue 01 (2016)

Pg. no. 10-16

Institute of Research Advances

http://research-advances.org/index.php/RAJMSS

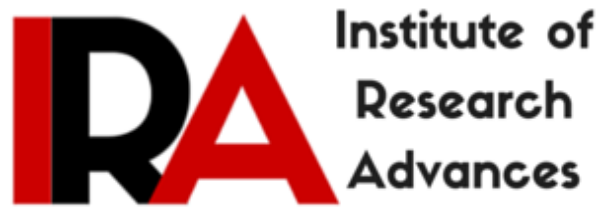

\title{
Effect of Emotional Advertisement on quitting smoking: A Case of Korean College Students
}

\author{
${ }^{1}$ Maidul Islam \\ Global Business Department \\ The University of Suwon, South Korea. \\ ${ }^{2}$ Shabnam Abdulkasem Sheikh \\ International College \\ The University of Suwon, South Korea.
}

Type of Review: Peer Reviewed.

DOI: http://dx.doi.org/10.21013/jmss.v5.n1.p2

\section{How to cite this paper:}

Islam, M., \& Sheikh, S. (2016). Effect of Emotional Advertisement on quitting smoking: A Case of Korean College Students. IRA-International Journal of Management \& Social Sciences (ISSN 2455-2267), 5(1), 10-16. doi:http://dx.doi.org/10.21013/jmss.v5.n1.p2

(C) Institute of Research Advances (cc) EY-NC

This work is licensed under a Creative Commons Attribution-Non Commercial 4.0 International License subject to proper citation to the publication source of the work.

Disclaimer: The scholarly papers as reviewed and published by the Institute of Research Advances (IRA) are the views and opinions of their respective authors and are not the views or opinions of the IRA. The IRA disclaims of any harm or loss caused due to the published content to any party. 


\begin{abstract}
In this research paper tried to focus on the effect of emotional anti-smoking ad on giving up smoking. More specifically, we have targeted college students to analysis the effect of non-emotional or less emotional and more emotional ads on quitting smoking. We have used 120 college students, were shown different anti-tobacco ads and asked to rate them. Our statistical results shows students who perceive ads are emotional and clear tend to quit smoking.
\end{abstract}

Keywords: tobacco, smoking, advertising, media, college students, South Korea

\title{
1. Introduction
}

Now a days, mass media works as influential tool in consumption of tobacco globally and works as good device for public institute by creating health awareness.. Through the media, people get useful and valuable information in some cases, and that is the reason why media are used widely almost everywhere. (McGuire, W. 1989). In modern race, people can easily approach to the media with help of smart phone, tabs, laptops, television or any other electronic devices, because there are so many different kinds of portable gadgets next to modern people's lives.

The impact or influence of mass media tool in consumption of tobacco globally could only be tested or confirmed if the smoker and non-smokers have been exposed to it and must have some interest on it (McGuire, W. 1989) . People who are exposed to the media will have reaction but people who are not exposed to the media will not have true reaction to it. Based on the Theory of Planned Behavior (TPB) and the Theory of Reasoned Action (TRA), individual's feeling predict behavior better even if many public campaigns emphasize on the individual's knowledge about the risk of disease (Ajzen, I, 1980; Ajzen I, 1991). It means touching people's emotional points work more efficiently to the purpose of the advertisement.

The effectiveness of anti-smoking media advertisement mostly depends on the factors like emotional subject matter, messages and theme (Beaudoin, C, 2002). Moreover, anti-smoking campaign which contains the emotional impact has the most powerful influence in tobacco use (TerryMcElrath, Y; Wakefield,M; Ruel, E; Balch, G.I; Emery, S; Szczypka, G; Clegg-Smith, k; Flay, $\mathrm{B}, 2005)$.

Based on the above points, we aimed to examine whether the emotional factors in anti-smoking advertisement has more impact on tobacco use or some other factors play more important role ? To come to a conclusion we have collected data, perform statistical analysis and draw a conclusion in the later part of this paper. The samples for this research study were taken mostly from Suwon University, South Korea..

\section{Literature Review}

International Advertising Association (I.A. A. Inc.) has defines the public service advertising communication as a form of advertising to accept the prevailing opinion of the public, which is recommended to support the activities or work that is beneficial to them as a social, economical way. According to the results of the Flora and Mailbach, in the public service announcement message evaluation it found that the emotional appeal advertising is better remembered than rational advertising appeal (Flora and Mailbach. 1990). In our research paper we mainly focused on the reaction of emotional anti-smoking ads on smoker and non-smoking of Korean college students.

\section{Tobacco control}

Controlling tobacco use is an international public health issue, several international public health policy makers dedicated to address this problem. Tobacco control is a main concern area for the World Health Organization (WHO), however references to a tobacco control movement either 
have positive or negative implications. In 2013, at Geneva, WHO reported on the Global Tobacco Epidemic ( Joossens, L. Raw, M. 2014). In their report WHO consequently shaped globally acceptable and widely recognized summary of tobacco control strategy, publicized as follows (source: Wikipedia)

- Monitor tobacco use and prevention policies

- Protect people from tobacco smoke

- Offer help to quit tobacco use

- Warn about the dangers of tobacco

- Enforce bans on tobacco advertising, promotion and sponsorship

- Raise taxes on tobacco

Indian Government in 2003 passed an Act to restrict advertisement, trade regulation of tobacco and tobacco related products. Bhutan also turned serious attention on Tobacco control act in 2010, which regulate the cultivation, harvesting, and production of tobacco and its associated products in Bhutan.

\section{Emotional appeal}

Advertising appeal is persuasive technique used in advertisement expression to draw psychological effects by hierarchy of customers (Aaker, Stayman, 1992). Advertising appeal is divided into rational appeal and emotional appeal by visual expression and the ways of advertising message. This study focused on whether emotional appeal affects students' intention to quit smoking. Emotional appeal is defined by Puto and Wells (1984) as a way of persuading a customer using abstract and emotional expression. Kotler divided emotional appeal into positive appeal and negative appeal. Positive appeal rouses the feelings of love, humor, pride, pleasure and negative appeal produces the feelings of threat, guilty, and shame (Kotler, 1971). In other words, positive appeal attempts to persuade them to change their attitudes and action by giving the expectation of some gain from a specified act. On the other hand negative appeal emphasizes that a negative result will occur and tries to persuade them by offering recommendations to avoid negative consequences. In an antismoking campaign, emotional appeal is more likely to highlight the loss caused by smoking or eventually express presents benefit from not smoking. On the contrary, emotional appeal of advertising messages can be defined as expressing negative outcomes caused by smoking abstractly, emotionally, and subjectively in this research.

\section{Methodology}

\section{Sampling Methodology}

This study was conducted in Korea between months of April to June 2016. A convenience sample of 134 students participated in this study, aged ranged from 20 to 26 years. However 14 questionnaires were not properly answered and were excluded from our study. Therefore a total of 120 samples were used for our research, wherein majority of the sample are female $84(70 \%)$ and 36(30\%) male.

Table 1. Descriptive Statistics of the sample

\begin{tabular}{ccccc}
\hline & Category & Frequency & $\begin{array}{c}\text { Percent } \\
(\%)\end{array}$ & $\begin{array}{c}\text { Cumulative } \\
\text { Percentage (\%) }\end{array}$ \\
\hline \multirow{2}{*}{ Gender } & Female & 84 & 70 & 70 \\
& Male & 36 & 30 & 100 \\
\hline \multirow{6}{*}{ Age } & 20 & 22 & 18,3 & 18.3 \\
& 21 & 9 & 7.5 & 25.8 \\
& 22 & 18 & 15 & 40.8 \\
& 23 & 21 & 17.5 & 58.3 \\
& 24 & 15 & 12.5 & 70.8 \\
& 25 & 20 & 16.7 & 87.5 \\
& 26 & 15 & 12.5 & 100 \\
\hline
\end{tabular}


The survey was conducted online as Korea is a tech savvy nation, placed second after Japan( thetoptens.com) and majority of Korean students are familiar with the technology. However to get quick responses, we adopted online survey to see the behavioral change among adult smokers, several types of messages that are most effective, and the degree to which impacted televised media campaigns effectively influence students who are affected by tobacco use. The survey was collected during three months in 2016. The survey aimed to know the content of anti-smoking advertising is more effective recognize when anti-tobacco TV advertisements was clear and emotional to people.

Initially the participants were given shortened version of Global Youth Tobacco Survey (GYTS) questionnaire. Based on the questionnaire we have categorized participants in "Smokers" if they mentioned any tobacco use during last month. Whereas other groups were defined as "Non- smoker" if they answered "Definitely not" to the questions.

Later parts of the survey, the students were randomly shown 2 different anti-tobacco TV advertisements. The advertisements are described in this table 2 .

Table 2. Ads and its Key message

\begin{tabular}{ll}
\hline Title & Key Message \\
\hline Family violence & Secondhand smoke is invisible violence. \\
Lung & Your lung is suffering from smoking \\
\hline
\end{tabular}

After each ad was shown, the subjects were requested to respond to specific question in relation to the characteristics of the anti-tobacco ads. At first, they were request to answer if the TV-advertisement was "clear to them", "that ad had a trivial message important to them", does make them "stop and think". These questions were targeted to judge or evaluate their response to the advertisement and how it influences their attitude towards smoking. All responses were gave on 1-7 point likert scale, where $1=$ strongly disagree to $7=$ strongly agree. Participants were also asked to inform their perceived emotional condition as well as how much each video made them uncomfortable, angry, happy and scared. They were also asked if the feel the ads were funny, boring or emotional. To explore how students perceived about the TV advertisement as effective or not a 7 point likert scale question was incorporated in the questionnaire.

\section{Statistical Analyses}

To analysis our collected data primarily we performed chi-squared test to determine whether there is a significant association between the descriptive characteristics of the study population and their basic responses. Regression analysis allowed for the investigation into how the students perceived the ads as powerful according to the ads characteristics and emotional context. The statistical analysis was carried out with the SPSS 22.0 statistical package.

\section{Results}

Totally, 120 university students participated in this study, out of which 84 were female (70\%) and 36 male (30\%). The mean age of the participants was 23 years of age (range 20-26), and the number of smokers is 41 persons, and the number of non-smokers were examined 79 persons among the 120 participants.

Emotional anti-smoking advertisement and non-emotional anti-smoking advertisement, advertisements were shown to the participant to investigate which advertisement is effective in stopping smoking .Participants were asked to watch the advertisement and rate them with a likert scale of 1-7 to check their emotional impact, where 1 was less emotional impact 7 was higher emotional impact. Table 2 show Percentage and number of students that rated each question with a 57 score on. Table 3 Percentage and number of students showed whether Smoking and non-smoking among participants of the answer 5-7. As represented in table 3. Analysis unveil that Family violence smoking advertisement was the answer to that play highest emotional impact and notably number of non-smokers was higher in the group received the effective impact. Whereas anti-smoking 
advertisement focuses on Lungs was found to be distressing and also score comparatively higher in Boringness. Most of the participants who have indicated this reaction appeared to be non-smokers.

Table 3. Percentage and number of students that rated each question with a 5-7 score on.

\begin{tabular}{|lll|}
\hline \multicolumn{2}{|l|}{ Family Violence \% (n) } & Lung $\%(\mathrm{n})$ \\
\hline This ad... & & \\
\hline Was clear & $81.7(98)$ & $56.7(68)$ \\
\hline Had a message that is important to me & $50(60)$ & $36.6(44)$ \\
\hline Made me stop and think & $43.3(52)$ & $34.1(41)$ \\
\hline This ad made me feel... & & $81.6(98)$ \\
\hline Uncomfortable & $60.8(73)$ & $42(34)$ \\
\hline Angry & $25.9(31)$ & 0 \\
\hline Happy & $0.8(1)$ & $64.2(77)$ \\
\hline Scared & $41.7(50)$ & $9.2(11)$ \\
\hline This ad was... & & $30.8(37)$ \\
\hline Funny & $3.4(4)$ & $7.5(9)$ \\
\hline Boring & $13.3(16)$ & $59.2(71)$ \\
\hline Emotional & & \\
\hline
\end{tabular}

Result also indicated that the participants were scared (64.2\%), Angry (42\%) of seeing Lung related ads than other type of ads as depicted in Table 3 .

Table 4. Percentage that rated the media campaigns as effective (5-7 score) by smoking status.

\begin{tabular}{|llll|}
\hline & $\begin{array}{l}\text { Total study } \\
\text { population }\end{array}$ & $\begin{array}{l}\text { Smokers } \\
(\%)\end{array}$ & $\begin{array}{l}\text { Non smokers } \\
\%(\mathrm{n})\end{array}$ \\
\hline Family violence & 120 & $20 \%(24)$ & $40.8 \% \quad(49)$ \\
Lung & 120 & $1.7 \%(2)$ & $8.3 \%(10)$ \\
\hline
\end{tabular}

As shown in the table 4, we investigated into how the university student perceived the viewed media advertising as effective by smoking status, through rating them with a 5-7 score (effective- very effective) on the Likert scale in response to the question, "How effective is this advertising as part of an anti-smoking advertising".

Compared to smokers, non-smokers are accepted as more emotional; effective among the participants watched the family violence anti-smoking advertisement (40.8\%). When it is come to lungs antismoking advertisement non-smoker showed more concern than smoker. Non-smokers rated its 5 times more emotionally $(8.3 \%)$ important than smokers. 
Table 5. Model summary

\begin{tabular}{|c|c|c|c|c|c|c|c|c|c|c|}
\hline \multirow[b]{2}{*}{ Model } & \multirow[b]{2}{*}{$\mathrm{R}$} & \multirow[b]{2}{*}{$\begin{array}{l}\mathrm{R} \\
\text { square }\end{array}$} & \multirow[b]{2}{*}{$\begin{array}{l}\text { adjusted } \\
\text { R Square }\end{array}$} & \multirow{2}{*}{$\begin{array}{l}\text { Std. } \\
\text { Error of the } \\
\text { Estimate }\end{array}$} & \multicolumn{6}{|c|}{ Change statistics } \\
\hline & & & & & $\begin{array}{l}\mathrm{R} \\
\text { Square } \\
\text { change }\end{array}$ & F change & df1 & df 2 & $\begin{array}{l}\text { sig. } \\
\text { Change }\end{array}$ & \\
\hline 1 & .867 & .752 & .750 & .647 & .752 & 358.015 & 1 & 118 & 000 & \\
\hline 2 & .450 & .203 & .196 & 1.010 & .203 & 29.989 & 1 & 118 & 000 & \\
\hline
\end{tabular}

Table 5 displays $\mathrm{R}, \mathrm{R}$ squared, adjusted and the standard error. $\mathrm{R}$ is the correlation between observed and the predicted values of the dependent variable. The absolute value of $\mathrm{R}$ indicates the strength with larger absolute values indicating strong relationships. In above table both model showed significant $\mathrm{F}$ change which is less than 0.05 which prompt that data collected for this research well fit with the research methods.

Table 6. ANOVA

\begin{tabular}{|c|c|c|c|c|c|c|}
\hline Model & & $\begin{array}{l}\text { Sum } \\
\text { Squares }\end{array}$ & $\mathrm{df}$ & $\begin{array}{l}\text { Mean } \\
\text { Square }\end{array}$ & $\mathrm{F}$ & Sig. \\
\hline \multirow{3}{*}{1} & Regression & 30.598 & 1 & $30.59,8$ & 29.989 & .000 \\
\hline & Residual & 120.394 & 118 & 1.020 & & \\
\hline & Total & 150.992 & 119 & & & \\
\hline \multirow{3}{*}{2} & Regression & 149.663 & 1 & 149.663 & 358.015 & 000 \\
\hline & Residual & 49.328 & 118 & 418 & & \\
\hline & Total & 198.992 & 119 & & & \\
\hline
\end{tabular}

In table 6 the $\mathrm{F}$ statistic is the regression mean square divided by the residual mean square and the significant value of $\mathrm{F}$ change is less than 0.05 which clearly indicated that the independent variables( advertisement) do a good job explaining the variation in the dependent variable(quitting smoking)

\section{Conclusion}

On the basis of this study college students in Korea pay much more attention on clarity of the emotional advertisements and found more effective in changing people mind to quit smoking. This study shows that among college students, the effectiveness of a media anti-tobacco TV campaign is strongly related to the ads clarity as well as emotionality to make them "stop and think". Contrasting on the global literature with our paper, we can conclude that emotional ads could address broader population (Biener, Wakefield, Shiner, Siegel, 2008; Biener, McCallum, Nyman, 2000). Though our paper included only Korean college students but earlier papers suggested students have more or less similar culture across nations, and focusing on anti-tobacco message among college students are more effective ( Murphy, Hyland, Higbee, 2008 ). In our earlier section of this research we have mentioned and included sadness, anger, fear because these are the important emotional domains that influence a message to be recalled whereas funny, happy or boring ads was not. Similar conclusion was drown by Biener, Gilpin, Albers, (2004) in their research work. Respondent also agreed on frequent exposure to anti-tobacco advertising shifts attitudes and believes that subsequently lead to behavior change.

As this study was focused only on college students, therefore there is an issue of generalizability of the result, which could be one the biggest limitation of this research. Beside that the sample size is 120 which are reasonable, however larger sample size can draw better conclusion. Furthermore samples were only collected from Suwon University, adding sample from several other universities could have given a comprehensive result, which could be another limitation. 
The present study gives clear indication that emotional advertisements which include, sadness, anger, fear could be more efficient than non-emotional funny ads. Government should play vital role to select emotional ads and broadcast frequently to reduce number of smoker and improve health condition of its citizen

\section{Reference}

Aaker, David A., and Douglas M. Stayman (1992 May), "Implementing The Concept Of Transformational Advertising," Psychology \& Marketing, 9, 237-253.

Ajzen, I. The theory of planned behavior. Organ. Behav. Hum. Decision Proc. 1991, 50, 179-211.

Ajzen, I.; Fishbein, M. Understanding Attitudes and Predicting Social Behavior; Prentice Hall: Englewood Cliffs, NJ, USA, 1980.

Beaudoin, C. Exploring antismoking ads: Appeals, themes and consequences. J. Health. Commun. 2002, 7, 123-137.

Biener, L.; McCallum-Keeler, G.; Nyman, A.L. Adults' response to Massachusetts anti-tobacco television advertisements: impact of viewer and advertisement characteristics. Tob. Control 2000, 9, 401-407.

Biener, L.; Wakefield, M.; Shiner, C.M.; Siegel, M. How broadcast volume and emotional content affect youth recall of anti-tobacco advertising. Am. J. Prev. Med. 2008, 35, 14-19.

Biener, L.; Ji, M.; Gilpin, E.; Albers, A.B. The impact of emotional tone, message, and broadcast parameters in youth antismoking advertisements. J. Health Commun. 2004, 9, 259-274.

Christopher P. Puto and William D. Wells (1984), "Informational and Transformational Advertising: the Differential Effects of Time", in NA - Advances in Consumer Research Volume 11, eds. Thomas C. Kinnear, Provo, UT : Association for Consumer Research, Pages: 638-643

Flora, J. A., \& Maibach, E. (1990). Cognitive responses to AIDS information: The effects of issue, involvement and message appeal.Communication Research, 17, 759-774

Kotler P, Zaltman G. Social Marketing: An Approach to Planned Social Change. Journal of Marketing 1971; 35 (July): 3-12.

Luk Joossens \& Martin Raw (2014)The Tobacco Control Scale 2013 in Europe. A report of the association of European Cancer Leagues.

McGuire, W. Theoretical Foundations of campaigns. In Public communication campaigns, 2nd ed.; Rice, R.E., Atkin, C.K., Eds.; Sage: Newbury Park, CA, USA, 1989; pp. 43-65.

Murphy-Hoefer, R.; Hyland, A.; Higbee, C. Perceived effectiveness of tobacco countermarketing advertisements among young adults. Am. J. Health Behav. 2008, 32, 725-734.

Terry-McElrath, Y.; Wakefield, M.; Ruel, E.; Balch, G.I.; Emery, S.; Szczypka, G.; Clegg-Smith, K.; Flay, B. The effect of antismoking advertisement executional characteristics on youth comprehension, appraisal, recall, and engagement. J. Health Commun. 2005, 10, 127-143. 